\title{
Experimental Study on Hygrothermal Performances of Indoor Covering Materials
}

\author{
Stefania Liuzzi * and Pietro Stefanizzi \\ Technical University of Bari, via Orabona 4, I-70125 Bari \\ Email: stefania.liuzzi@poliba.it
}

\begin{abstract}
Several clayey materials were prepared in Thermophysical Laboratory of Bari. Hygrothermal properties were measured according to technical standards. In order to consider the potential of earthen materials to improve indoor comfort, the software WUFI ${ }^{\circledR}+$ was used to simulate the hygrothermal behavior of a Test Room, placed in a Mediterranean climate. The analysis was carried out considering the internal surface of the walls of the building covered by five different plasters. Results demonstrated that when considering an unconditioned scenario (without HVAC system) Clay-Straw and Lime-Bentonite lead up to a greater improvement of the hygric performances, unlike traditional coverings as Gypsum or Ceramic tiles. It can be appreciated a greater damping relative humidity and sorption capacity of the earthen coatings. However, in presence of HVAC system any significant variations occurs in terms of energy saving.
\end{abstract}

Keywords: Building simulation, Energy saving, Hygrothermal behavior, Moisture buffering value, Test Room.

\section{INTRODUCTION}

Clay, one of the most common mineral present in loam, has been one of the most widely used materials in building construction. Bricks, ceramic tiles, mortars and plasters made with unbaked clay can be found worldwide.

Several studies have investigated the hygrothermal properties of unfired clayey materials and have shown their potential for passive buffering of relative humidity fluctuations in building physics applications [1-6].

Some researchers have performed experimental measurements of the thermal properties of unfired clayey building materials [7-8]. It was demonstrated that unfired earth can reach values comparable to the limits of fired clay.

Furthermore, several studies $[1,3,10,11]$ demonstrated that unfired clayey materials can provide better hygrothermal performances in comparison with common building materials like fired clay and cement.

Allinson and Hall [1, 3] characterized the hygric and thermal properties of cement-stabilised rammed earth materials. Minke [11] has demonstrated that when using a clayey plaster a significant water absorption rate occurs in the first $2 \mathrm{~cm}$ thick layer of the wall when the indoor air humidity raises from $30 \%$ to $70 \%$.

Liuzzi et al. [12] performed a study on hygrothermal behaviour and relative humidity buffering of unfired and hydrated lime-stabilized clay composites, using different type of clay (bentonite, quarry fine and kaolinite).

Murray [13] and Reeves et al. [14], showing the differences between various clays including kaolinite and bentonite, listed the most important physical and chemical characteristics that influence the behavior.

The additives can improve the hygrothermal performances (thermal insulation, water vapour permeability, equilibrium moisture content, buffering capacity), mechanical strengths (compressive, tensile, binding strength), resistance to weather conditions (rain and frost erosion, running water), swelling/shrinkage, and workability of the composite.

Ashour et al. [2, 15, 16] testing earth plasters reinforced with different fibers, has pointed out that the shrinkage of plasters is influenced by several factors, e.g. curing temperature, fiber content, fiber type and plaster compositions.

It was demonstrated that the equilibrium moisture content of plaster reinforced with barley straw is slightly higher than the other materials examined: shavings, wheat straw, and earth plaster without fiber. The relative humidity has greater effect on the change of moisture content than temperature. Increasing the fiber content thermal insulation and moisture content greatly increases.

Insulating materials using palm tree fibers and seaweed in a cement matrix were tested in [17]. Their properties were a function of the fiber content mass ratios with values that are comparable to synthetic insulating materials.

This study focuses on the hygrothermal behaviour of a Test Room in a Mediterranean climate with different materials as interior wall coatings. The aim of the paper is to better understand and quantify how the hygric mass of the unbaked clayey materials can improve the indoor environmental conditions. 
There are an increasing number of computer models [18] that can model heat and mass transfer in building materials.

PC software tool WUFI ${ }^{\circledR}$ Plus was chosen for the analysis in this paper. This software has been extensively validated and developed by the Fraunhofer Institute for Building Physics in Germany, for "the calculation of transient internal climatic conditions and heat losses by combination of energetic whole building simulation with hygrothermal component calculation" $[19,20]$.

\section{EXPERIMENTAL STUDY}

Samples of Clay-Straw plaster (TP4) and Bentonite-Lime plaster (C5) were prepared and tested in laboratory. The mix design is provided in table 1 .

The mixture TP4 has 4\% wt of barley straw. The blends were prepared by a mixer after several tests in order to define the exact amount of water to add. The specimens were cured for 7 days in a moist tank and 21 days at ambient temperature and relative humidity.

Table 1. The mixtures design - Soil components (\%wt)

\begin{tabular}{lllllll}
\hline Mix & C/S & B & SN & G & L & S \\
\hline TP4 & 40 & - & 58 & 2 & - & 4 \\
C5 & 33 & 7 & 58 & 2 & 5 & - \\
\hline
\end{tabular}

(C/S=Clay/Silt; B=bentonite; $\mathrm{SN}=$ Sand; $\mathrm{G}=$ Gravel; L=Lime; $\mathrm{S}=$ Straw).

The bulk density $\left(\rho_{d r y}\right)$ was measured as mass, of dried material, divided by volume.

The true density $\left(\rho_{\text {true }}\right)$ was measured with the Ultrapyc 1200-e Quantachrome Helium gas Pycnometer. Then the porosity $(n)$ was calculated as:

$n=1-\frac{\rho_{\text {dry }}}{\rho_{\text {true }}}$

Thermal properties were measured by a transient plane heat source device, the Isomet 2104 apparatus (Figure 1).

The dry state thermal conductivity $(\lambda)$ and dry state thermal diffusivity $(\alpha)$ were determined after oven drying at $105^{\circ} \mathrm{C}$ to constant mass and leaving the samples in desiccators with silica gel until reaching the ambient temperature.

The specific heat capacity was calculated as:

$C_{p}=\frac{\lambda}{\rho \alpha}$

The water vapour permeability $\left(\delta_{p}\right)$ and the water vapour resistance coefficient $(\mu)$ of specimens were determined according to UNI EN 1015-19 [21].

According to UNI EN ISO 12571 [22] the sorption isotherms were measured on samples of size $4 \mathrm{~cm} \mathrm{x} 4 \mathrm{~cm} \mathrm{x} 1$ $\mathrm{cm}$ in the climatic chamber (Perani AC520) at constant temperature $\left(23^{\circ} \mathrm{C}\right)$ at different values of relative humidity, $w_{80}$ was the equilibrium moisture content at $80 \%$ of air relative humidity.

Measurements were performed on three samples for each blend.
In order to avoid slaking of the unstabilized materials in liquid water, the free water saturation $\left(w_{f}\right)$ was estimated using the Künzel approximation [23].

According to UNI EN ISO 15148 [24], the water absorption coefficient $\left(A_{w}\right)$ is assessed putting one face of the specimen, previously oven dried to constant mass, in water for a small height and weighting at specific time intervals the mass increase.

Hygrothermal properties for the other materials (Gypsum, Vapour Barrier, Ceramic tiles) were assumed from WUFI's database of materials.

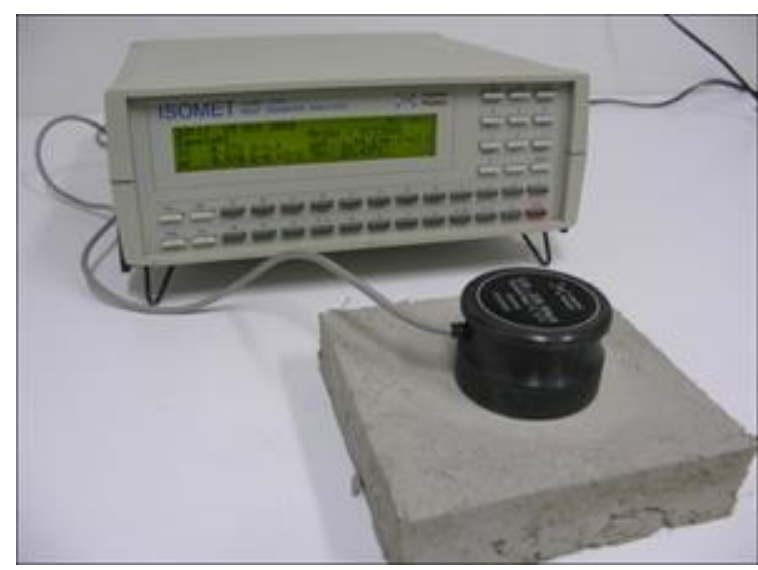

Figure 1. Isomet 2104 (Applied Precision Ltd.)

The main physical and hygrothermal parameters for the investigated materials are provided in Table 2.

Table 2. Thermophysical data used for simulations

\begin{tabular}{llllll}
\hline & $\begin{array}{l}\text { Clay- } \\
\text { Straw } \\
\text { TP4 }\end{array}$ & $\begin{array}{l}\text { Lime- } \\
\text { Bentonite } \\
\text { C5 }\end{array}$ & $\begin{array}{l}\text { Gypsum } \\
\text { GY }\end{array}$ & $\begin{array}{l}\text { Vapour } \\
\text { Barrier } \\
\text { VB }\end{array}$ & $\begin{array}{l}\text { Ceramic } \\
\text { tiles } \\
\text { GR }\end{array}$ \\
\hline $\boldsymbol{\rho}_{\boldsymbol{d r y}}\left[\mathrm{kg} / \mathrm{m}^{3}\right]$ & 1384 & 1843 & 1273 & 130 & 1700 \\
\hline $\boldsymbol{n}[-]$ & 0.441 & 0.315 & 0.530 & 0.001 & 0.095 \\
\hline $\boldsymbol{C}_{\boldsymbol{p}[\mathrm{J} / \mathrm{kg} \mathrm{K}]}$ & 1034 & 766 & 850 & 2300 & 1000 \\
\hline $\boldsymbol{\lambda}_{\boldsymbol{d r y} \boldsymbol{y}}[\mathrm{W} / \mathrm{m} \mathrm{K}]$ & 0.340 & 0.892 & 0.430 & 2.300 & 1.470 \\
\hline $\boldsymbol{\mu}[-]$ & 11.0 & 9.3 & 7.5 & 32800 & 54.0 \\
\hline $\boldsymbol{w}_{80}\left[\mathrm{~kg} / \mathrm{m}^{3}\right]$ & 29.5 & 39.7 & 2.5 & $\sim 0$ & $\sim 0$ \\
\hline $\boldsymbol{w}_{\boldsymbol{f}}\left[\mathrm{kg} / \mathrm{m}^{3}\right]$ & 273.6 & 234.5 & 183.0 & $\sim 0$ & $\sim 0$ \\
\hline $\boldsymbol{A}_{\boldsymbol{w}}\left[\mathrm{kg} / \mathrm{m}^{2} \mathrm{~s}^{0,5}\right]$ & 0.052 & 0.180 & 0.260 & $\sim 0$ & $\sim 0$ \\
\hline & & & & & \\
\hline
\end{tabular}

\section{HYGROTHERMAL SIMULATION}

\subsection{Test room and boundary conditions}

A single Test Room, placed in a Mediterranean climatic context (climate station of Bari-Palese), was modeled.

The Test Room (Figure 2) was supposed to be a double bedroom with internal dimensions $5.5 \times 3.6 \mathrm{~m}^{2}$ and height 2.8 $\mathrm{m}$. On the vertical wall south facing there is a window of 2.55 $\mathrm{m}^{2}$. On the top of the window, $10 \mathrm{~cm}$ far apart, is inserted an overhang of $1 \mathrm{~m}$ depth for solar protection. 
The room is defined as part of a building and one wall adjoins the outer climate. There is no heat exchange over the inner walls, floor and ceiling to the adjacent rooms. On the southern side, the building borders with the outdoor environment; the adjacent rooms were set having the same indoor temperature and relative humidity of the Test Room.

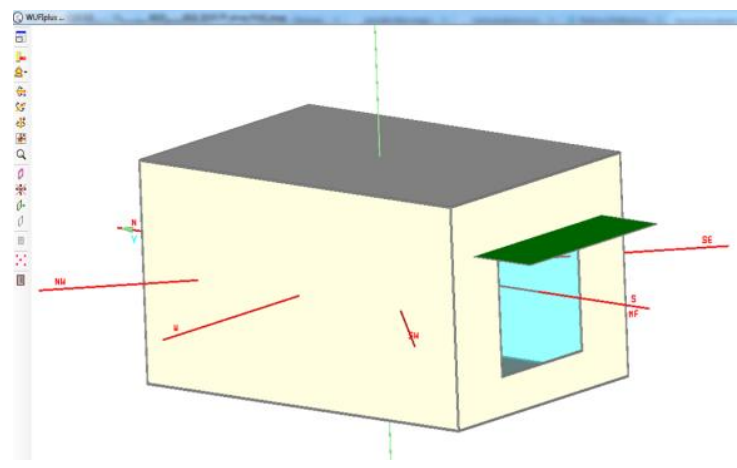

Figure 2. Test Room

The walls consisted of lightweight fired bricks of $30 \mathrm{~cm}$ thickness, covered by an external cement-gypsum plaster. On the internal side there were supposed five different coatings of $2 \mathrm{~cm}$ thickness:

1) Clay-Straw plaster (TP4);

2) Bentonite-Lime plaster (C5);

3) Gypsum plaster (GY);

4) Gypsum plaster with a waterproof wallpaper (Vapour Barrier, VB);

5) Ceramic tiles (Gres, GR).

A thermal transmittance of about $0.31 \mathrm{~W} / \mathrm{m}^{2} \mathrm{~K}$, for the opaque walls, was calculated for all the assemblies.

Common cement floor slabs were supposed with an insulation cork layer of $3 \mathrm{~cm}$ thickness. A thermal transmittance of about $0.70 \mathrm{~W} / \mathrm{m}^{2} \mathrm{~K}$ was calculated for the horizontal assemblies.

The window, with a low-emissivity double glass, has a thermal transmittance of $1.99 \mathrm{~W} /\left(\mathrm{m}^{2} \mathrm{~K}\right)$ and a sunscreen device operating in a way to reduce overheating.

The Test Room was supposed to be occupied 7 days a week by two occupants at rest, during the night, between 11.00 p.m. to 9.00 a.m., and one occupant at rest, in the afternoon, between 3.00 p.m. and 5.00 p.m. For each user the convection heat transfer was supposed to be $65 \mathrm{~W}$, radiation heat transfer was set as $36 \mathrm{~W}$ and the water vapor rate produced in the room was supposed of $43 \mathrm{~g} / \mathrm{h}$. Furthermore, natural ventilation, in terms of $\mathrm{ACH}$, was set constant to 0.5 $\mathrm{h}^{-1}$.

An overall summary of the internal gain schedule is shown in Table 3.

A first simulation was run over one year. It became clear that this period does not provide accurate and adequate results. Wihan [25] has demonstrated that it takes almost one year for materials within a wall assembly to gain perfect equilibrium with the surrounding environment. At least another year of data is needed for further investigations.

This is the reason why the simulation was set to run over a period of 2 year and the results, for the purpose of the present study, were considered on the second simulation year. The time step was set to 1 hour.

The analyzes were performed supposing two different scenarios: in the first one a passive house without HVAC was considered (Unconditioned scenario); in the second one an air conditioning system was taken into account (Conditioned scenario). This Hvac system is able to keep the indoor air at constant temperature of $20^{\circ} \mathrm{C}$ in winter and $26^{\circ} \mathrm{C}$ in summer, and at constant relative humidity of $50 \%$ all year long.

Table 3. Internal daily schedule

\begin{tabular}{|l|l|l|l|l|l|l|}
\hline Hour & $\begin{array}{l}\text { Occu- } \\
\text { pants }\end{array}$ & $\begin{array}{l}\text { Heat } \\
\text { convec } \\
\text {-tion } \\
{[\mathrm{W}]}\end{array}$ & $\begin{array}{l}\text { Heat } \\
\text { radiant } \\
{[\mathrm{W}]}\end{array}$ & $\begin{array}{l}\text { Mois } \\
\text {-ture } \\
{[\mathrm{g} / \mathrm{h}]}\end{array}$ & $\begin{array}{l}\text { Human } \\
\text { activity } \\
{[\mathrm{met}]}\end{array}$ & $\begin{array}{l}\text { Air } \\
\text { velo- } \\
\text { city } \\
{[\mathrm{m} / \mathrm{s}]}\end{array}$ \\
\hline $\begin{array}{l}\text { 11 p.m. } \\
\text { - 9 a.m. }\end{array}$ & 2 & 130 & 72 & 86 & 0,97 & 0,1 \\
\hline $\begin{array}{l}3 \text { p.m. - } \\
\text { 5 p.m. }\end{array}$ & 1 & 130 & 72 & 43 & 0,97 & 0,1 \\
\hline
\end{tabular}

\subsection{Unconditioned scenario}

The results were initially examined for the room without HVAC system in passive inner climate. Figure 3 provides results in terms of relative humidity of the indoor air on July.

It can be appreciated a greater damping capacity of the clay-straw (TP4) plaster.

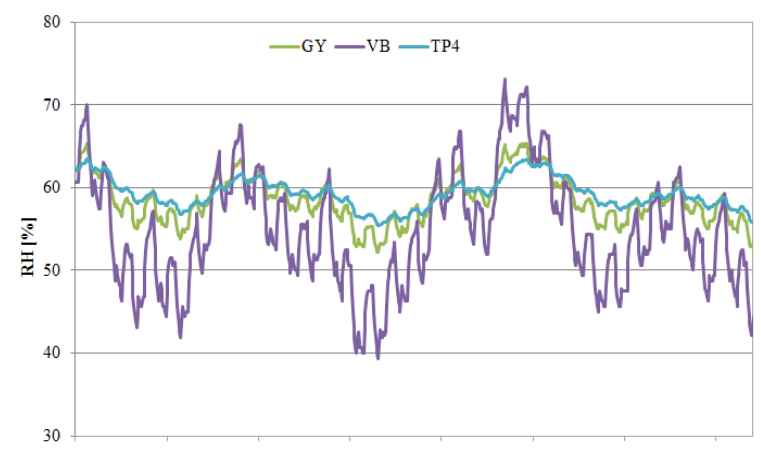

Figure 3. Relative humidity of indoor air, on July, for different coatings

This demonstrates a great buffering performance of these materials either in summer than in winter

From Figure 4 it can be seen that this moisture buffering has very little impact on the temperature of the indoor air as the temperature profiles generally are overlapping. This is because the building materials, having a similar thermal conductivity and thickness, show a similar thermal resistance.

The moisture buffering performance of clayey coverings is more evident in Figures 5-6, a lower range of variation of indoor relative humidity is obtained in the year.

Looking at the moisture exchange with partitions, ClayStraw and Bentonite-Lime plasters show the greatest values either in absorption than in desorption (Figure 7).

The comfort analyses by the adaptive model, according to UNI EN 15251 [26], provides the results reported in Figures 8-9 as Indoor Operative Temperature vs Outdoor Gliding Temperature, for TP4 and VB coverings respectively.

Operative temperature of Clay-Straw covering, fall into the comfort limits typical for a II category building (i.e. Normal level of expectation as for a new building and renovations), while Operative temperature of Waterproof Wallpaper covering fall into the comfort limits typical of a III category building (i.e. Acceptable, moderate level of expectation as for existing buildings). 


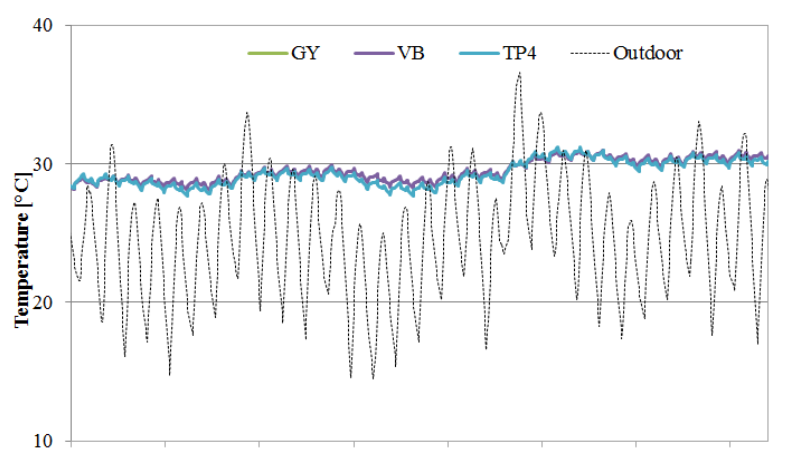

Figure 4. Outdoor temperature and temperature of indoor air, on July, for different coatings

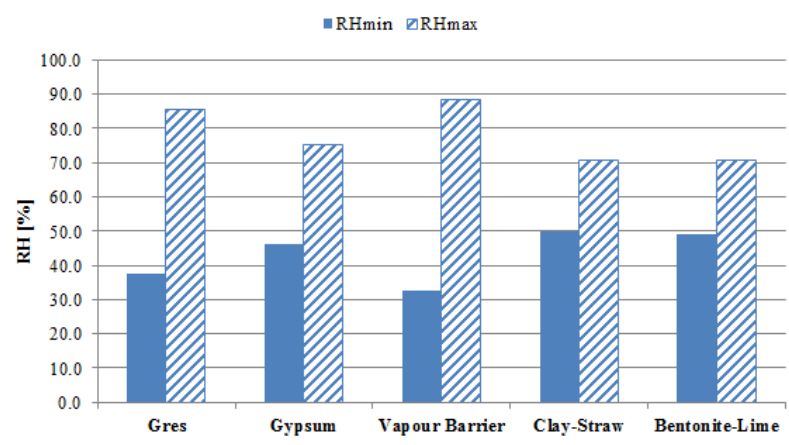

Figure 5. Relative humidity (max and min value) of indoor air, in the year, for different coatings

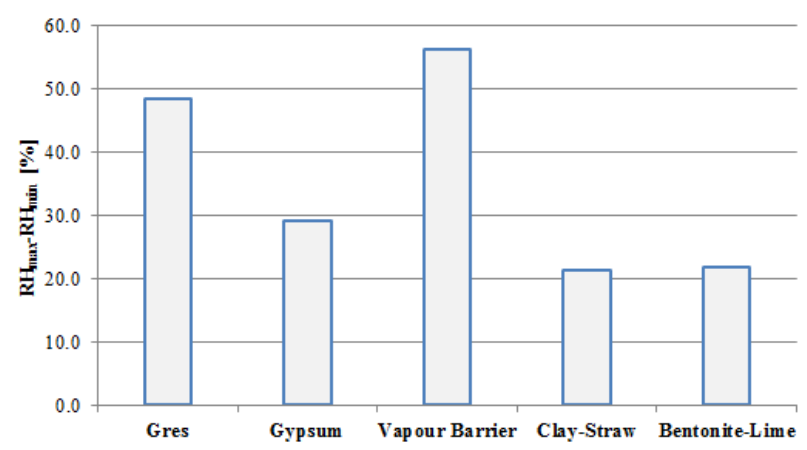

Figure 6. Relative humidity range (max-min) of indoor air, in the year, for different coatings

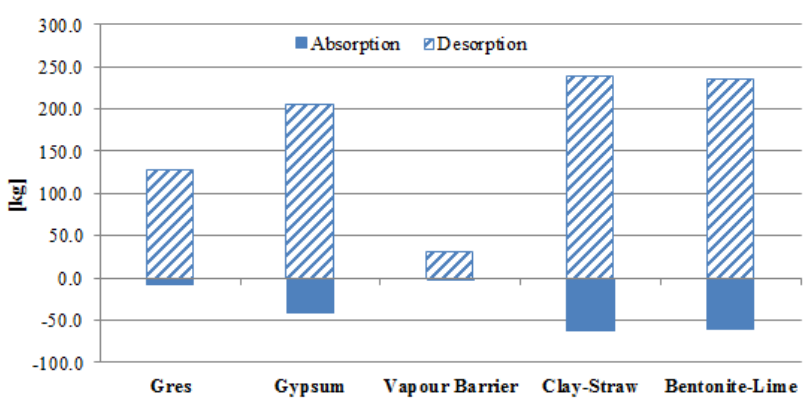

Figure 7. Moisture exchange with partitions (absorption and desorption) in the year, for different coatings

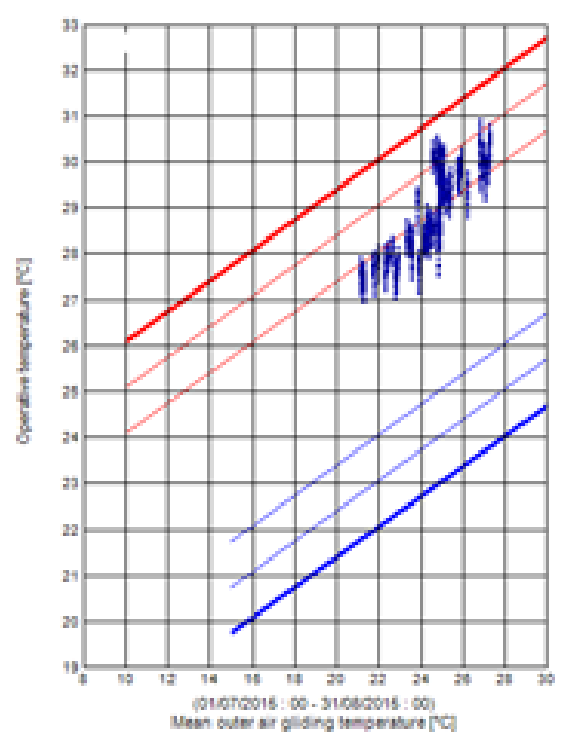

Figure 8. Indoor Operative temperature vs Mean outdoor gliding temperature (UNI EN 15251) for TP4 plaster, from $1^{\text {st }}$ July to $31^{\text {st }}$ August

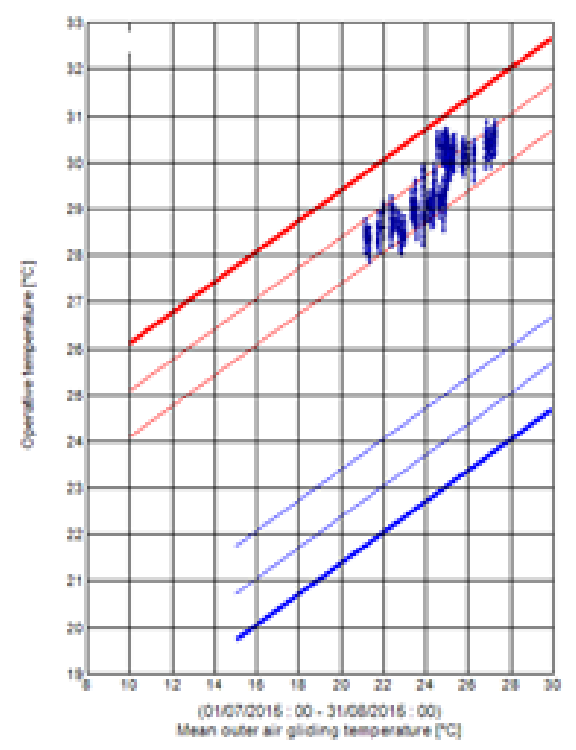

Figure 9. Indoor Operative temperature vs Mean outdoor gliding temperature (UNI EN 15251) for VB covering, from $1^{\text {st }}$ July to $31^{\text {st }}$ August

\subsection{Constantly conditioned scenario}

In order to improve the thermal comfort of the occupants it was considered a second scenario with an oversized HVAC plant for heating, cooling, humidification and dehumidification. Oversized means that HVAC gives all what is needed to maintain the desired indoor conditions (temperature and relative humidity).

The Test Room was simulated with new design conditions: $20{ }^{\circ} \mathrm{C}$ and $50 \%$ relative humidity in winter (i.e. from $15^{\text {th }}$ November to $31^{\text {st }}$ March); $26{ }^{\circ} \mathrm{C}$ and $50 \%$ relative humidity in the rest of the year (i.e. from $1^{\text {st }}$ April to $14^{\text {th }}$ November). 


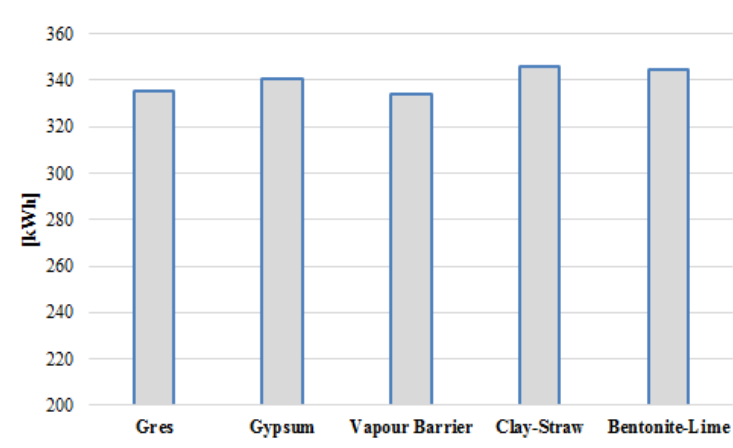

Figure 10. Latent heat for humidification and dehumidification in the year, for different coatings

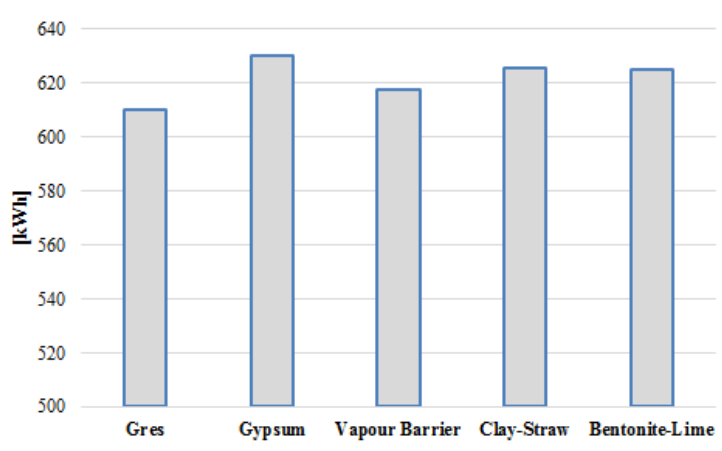

Figure 11. Energy demand for heating and cooling, in the year, for different coatings

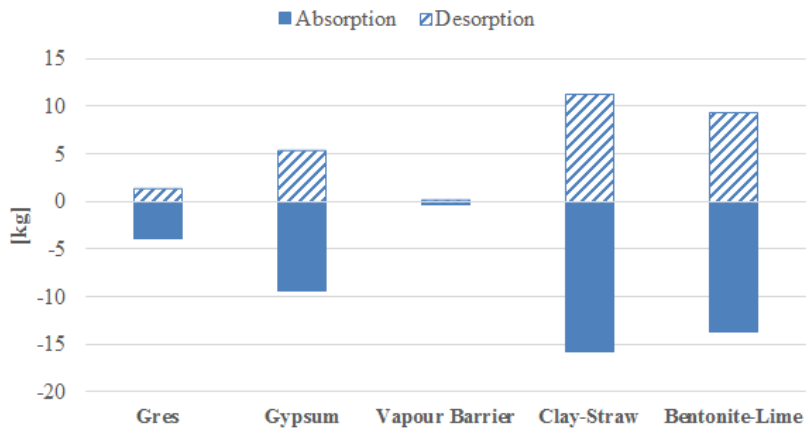

Figure 12. Moisture exchange with partitions (absorption and desorption) in the year, for different coatings

By looking at the energy demand for the humidification and dehumidification (Figure 10) it can be seen that any significant variation can be appreciated during the year. The annual energy demand for heating and cooling is shown in Figure 11. It can be note that comparing to gypsum covering, the energy requirement decreased when TP4 and C5 were used.

The yearly moisture flux between the walls and the indoor air is shown in Figure 12; the walls with TP4 and C5 demonstrate a greater moisture buffering capacity. It can be note that the TP4 plaster has a better sorption capacity than C5 plaster.

Figures 13-14 provide the yearly peak power for heating and cooling. By using the earthen materials, a decrease can be appreciated, perhaps due to their greater moisture buffering performance that influences the latent heat power request.

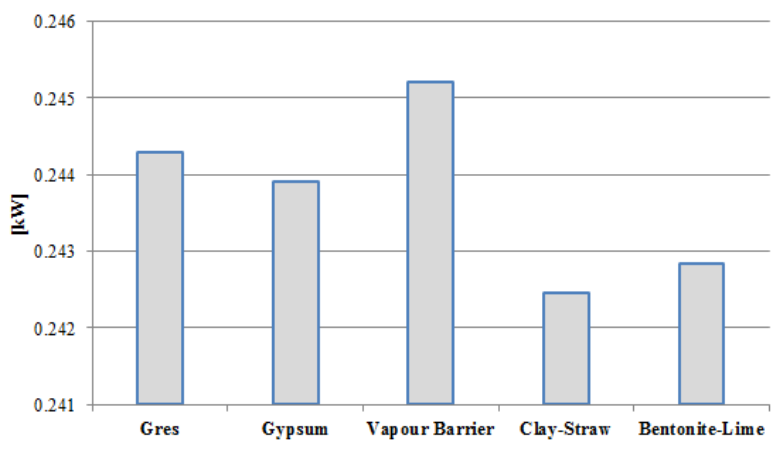

Figure 13. Peak power for heating in the year, for different coatings

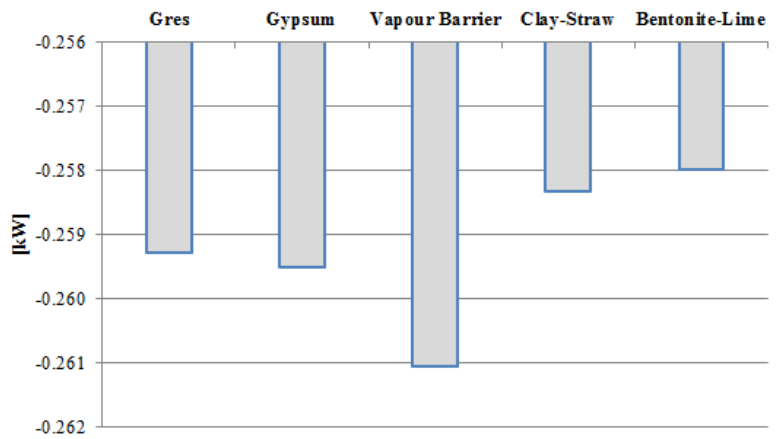

Figure 14. Peak power for cooling in the year, for different coatings

\section{CONCLUSIONS}

The hygrothermal parameters of the earthen building materials (TP4 and C5) were measured at Thermophysical Laboratory of University of Politecnico di Bari. The data of the traditional materials (Gypsum, Vapour Barrier and Ceramic tiles) were taken from WUFI ${ }^{\circledR}+$ database.

The indoor climate of a Test Room in a Mediterranean climate context was modeled using the software $\mathrm{WUFI}^{\circledR}+$. Considering a first scenario without HVAC system, the numerical simulations show that the TP4 plaster significantly dumps the amplitude of relative humidity fluctuations during both summer and winter in comparison with traditional materials with greater surface diffusion resistance.

The yearly range of variation of relative humidity demonstrates that the earthen coatings have a better moisture buffering performance comparing to the other coverings.

Furthermore, the results show that the earthen coverings have the greatest capacity to absorb and desorb the moisture content in the Test Room.

Considering an HVAC system, the yearly energy demand for humidification/dehumidification was studied. Any significant variations can be appreciated during the year for the five covering materials.

Considering the peak power for heating and cooling over the year, a decrease can be appreciated when using earthen coverings.

In conclusion, it can be asserted that the use of an earthen coating could realize better indoor comfort in free running conditions, without HVAC system. However, when HVAC system works, no significant variations occur, as well as no relevant energy saving is noted. 


\section{REFERENCES}

[1] D. Allinson and M. Hall, "Hygrothermal analysis of a stabilised rammed earth test building in the UK," Energy and Buildings, vol. 42, no. 6, pp. 845-852, June, 2010. DOI: 10.1016/j.enbuild.2009.12.005.

[2] T. Ashour, H. Georg and W. Wu, "An experimental investigation on equilibrium moisture content of earth plaster with natural reinforcement fibres for straw bale buildings," Applied Thermal Engineering, vol. 31, no. $2-3$, pp. 293-303, Feb. 2011. DOI: 10.1016/j.applthermaleng.2010.09.009.

[3] M. Hall and D. Allinson, "Analysis of the hygrothermal functional properties of stabilised rammed earth materials," Building and Environment, vol. 44, no. 9, pp. 1935-1942, Sept. 2009. DOI: 10.1016/j.buildenv.2009.01.007.

[4] S. Liuzzi, M. Petrella and P. Stefanizzi, "Building with earth, a sustainable material for efficient buildings," in XXXVII IAHS, Santander, Spain, 2010, October 26-28, 2010

[5] T. Padfield, "The role of absorbent building materials in moderating changes of relative humidity," $\mathrm{PhD}$ Thesis. Dep of Struct. Eng. and Mat., DTU University, Denm., 1999.

[6] B. Zhou and Z. Chen, "Experimental Study on the Hygrothermal Performance of Zeolite-Based Humidity Control Building Materials," Int J Heat \& Tech, vol. 34, no. 3, September 2016, pp. 407-414. DOI: 10.18280/ijht.340309

[7] J.E. Oti, J. M. Kinuthia and J. Bai, "Design thermal values for unfired clay bricks," Materials and Design, vol. 31, no. 1, pp. 014-112, Jan. 2010. DOI: 10.1016/j.matdes.2009.07.011.

[8] J. E. Oti, J. M. Kinuthia and J. Bai, "Engineering properties of unfired clay masonry bricks," Engineering Geology, vol. 107, no. 3-4, pp. 130-139, Aug. 2009. DOI: $10.1016 /$ j.enggeo.2009.05.002.

[9] M. L. Parra Saldivar and W. Batty, "Thermal behaviour of adobe constructions," Building and Environment, vol. 41, pp. 1892-1904, Dec. 2006. DOI: 10.1016/j.buildenv.2005.07.021.

[10] Y. Millogo, M. Hajjaji and R. Ouedraogo, "Microstructure and physical properties of lime-clayey adobe bricks, " Construction and Building Materials, vol. 22, pp. 2386-2392, Dec. 2008. DOI: 10.1016/j.conbuildmat.2007.09.002.

[11] G. Minke, "The properties of earth as a building material," Building with Earth, eds. Birkhäuser Basel, Switzerland, pp. 19-31, 2006. Available: http://www.rivendellvillage.org/Building_With_Earth. pdf

[12] S. Liuzzi, M. R. Hall, P. Stefanizzi and S. P. Casey, "Hygrothermal behaviour and relative humidity buffering of unfired and hydrated lime-stabilised clay composites in a Mediterranean climate," Building and Environment, vol. 61, pp. 89-92, March 2013. DOI: 10.1016/j.buildenv.2012.12.006

[13] H. H. Murray, Applied Clay Mineralogy. Elsevier Science, 2006.

[14] G. M. Reeves, I. Sims and J. C. Cripps, Clay Materials Used in Construction, Special Publication 21, Eds. Engineering Geology, Geological Society, London, 2006.

[15] T. Ashour and W. Wu, "An experimental study on shrinkage of earth plaster with natural fibres for straw bale buildings," International Journal of Sustainable Engineering, vol. 3, pp. 299-304, August 2010. DOI: 10.1080/19397038.2010.504379.

[16] T. Ashour, H. Wieland, H. Georg, F. J. Bockisch and $\mathrm{W}$. Wu. "The influence of natural reinforcement fibres on insulation values of earth plaster for straw bale buildings," Materials and Design, vol. 31, no. 10, pp. 4676-4685, Dec. $2010 . \quad$ DOI: 10.1016/j.matdes.2010.05.026.

[17] I. Boulaoued, I. Amara and A. Mhimid, "Experimental determination of thermal conductivity and diffusivity of new building insulating materials," Int J Heat \& Tech, vol. 34, no. 2, June 2016, pp. 325-331, DOI: 10.18280/ijht.340224.

[18] H. Hens, Final Report Task 1: Modelling Common Exercises. Summary Reports. Annex 24, Heat Air and Moisture Transfer in Insulated Envelope Parts, International Energy Agency, 1996.

[19] Fraunhofer Institute for Building Physics, WUFI, Available at: http://www.wufi.de/en, Accessed on 30 April 2016

[20] K. Lengsfeld and A. Holm, "Entwicklung und Validierung einer hygrothermischen RaumklimaSimulationssoftware WUFI ${ }^{\circledR}$-Plus," Bauphysik, vol. 29, no. 3, July 2007. DOI: 10.1002/bapi.200790042.

[21] "Methods of test for mortar for masonry Determination of water vapour permeability of hardened rendering and plastering mortars," UNI EN 1015-19, 2008.

[22] "Hygrothermal performance of building materials and products - Determination of hygroscopic sorption properties," UNI EN ISO 12571, 2013.

[23] H. M. Künzel, "Simultaneous heat and moisture transport in building components," Dissertation, University of Stuttgart, Stuttgart, 1995.

[24] "Hygrothermal performance of building materials and products - Determination of water absorption coefficient by partial immersion," UNI EN ISO 15148, 2003.

[25] J. Wihan, "Humidity in straw bale walls and its effect on the decomposition of straw," $\mathrm{PhD}$ Thesis, University of East London, 2007.

[26] "Indoor environmental input parameters for design and assessment of energy performance of buildings addressing indoor air quality, thermal environment, lighting and acoustics," UNI EN 15251, 2008.

\section{NOMENCLATURE}

$A_{w} \quad$ water absorption coefficient

$C_{p} \quad$ specific heat capacity

$n$ bulk porosity

$R H \quad$ relative humidity

$T$ temperature

$w \quad$ equilibrium moisture content

$\left[\mathrm{kg} /\left(\mathrm{m}^{2} \cdot \mathrm{s}^{0.5}\right)\right]$

$[\mathrm{J} / \mathrm{kg} \mathrm{K}]$

$\left[\mathrm{m}^{3} / \mathrm{m}^{3}\right]$

[\%]

$\left[{ }^{\circ} \mathrm{C}\right]$

$\left[\mathrm{kg} / \mathrm{m}^{3}\right]$

$w_{80}$ equilibrium moisture content at $\mathrm{RH}=80 \%$

$w_{f} \quad$ free water saturation $(\mathrm{RH}=100 \%)$

$\left[\mathrm{kg} / \mathrm{m}^{3}\right]$

$\delta_{p}$

$\lambda_{d r y}$

water vapour permeability

dry thermal conductivity

$\mu \quad$ water vapour resistance coefficient

$\rho_{d r y} \quad$ dry density

$\rho_{\text {true }}$ true density

\section{$\left[\mathrm{kg} / \mathrm{m}^{3}\right]$}

[kg/m s Pa]

$[\mathrm{W} / \mathrm{mK}]$

$[-]$

$\left[\mathrm{kg} / \mathrm{m}^{3}\right]$

$\left[\mathrm{kg} / \mathrm{m}^{3}\right]$ 